since I have been here, and each bit seems to be just as much the last and just as original as the one before. I must say, though, that it's unlike any bush I have ever seen, the ferns and the other native plants make it delightful.

'But I don't like your stumped paddocks. They look like the old battlefields on the Western Front, with the tree trunks all battered and smashed and burned by the shells. The Government should compel the owners to take them out - no expense should be spared for the sake of appearances.'

\title{
New Zealand, 1934: VI
}

From Ness Mackay, 'Farewell to GBS', Dominion (Wellington), 16 April 1934, reprinted in What I Said in NZ, p. 28. Ness Mackay interviewed Shaw on the deck of the Rangitane just before he sailed for England.

'We want to understand your duo-national views. You know, you have caused much consternation here by criticising ours!'

'Well, then,' he said, 'I did not use the word "sentimental" about you that learnt to call a distant country "Home" before you learnt to speak any other word. I apply the word "sentimental" to those absentee landlords of yours, who lived here, and worked here, and made money here, and now call England "Home" and go and live there, or make long trips there and spend their money there while you in New Zealand are trying to make a living out of what they leave. I have told some of your politicians that there ought to be a law to prevent these people taking all your money out of the country just now while you need it most.'

'Would that be Socialism, Mr Shaw?'

'That, my dear lady, would be sound sense. And there would be more sense, too, if England, which you call "Home" while you make tariff walls against her and then work yourselves to rages about her quotas, just shook you off. You Dominions! You all try to bleed her! I tell you this seriously: A day will come when England will just rebel and get out of "our Empire" as you call the game you play with her. She will, then!' said he with a tinge of a brogue and folded his arms and looked square down at me. 